\title{
Critical Analysis of the Influence of Organizational Citizenship Behavior on Turnover Intentions of Generation Y Employees in it Firms in India
}

\author{
*Renu Jahagirdar ${ }^{1}$, Dr. Swati Bankar ${ }^{2}$ \\ ${ }^{1}$ Dr.Vishwanath Karad MIT World Peace University, School of Management -PG \\ Email: renuj75@yahoo.co.in \\ ${ }^{2}$ Dr.Vishwanath Karad MIT World Peace University, School of Management -PG \\ Email : swati.bankar@mitwpu.edu.in
}

\begin{abstract}
Purpose- This research study has sought to assess the importance of organizational citizenship behavior to enhance the retention rate of the Generation Y employees of the Indian IT firm. The research study has provided a holistic viewpoint regarding the way the implementation of OCB can assist an IT firm to motivate their employees to provide their maximum efficiency towards the success of an organization. In addition, the research study has also demonstrated the characteristics of Gen Y IT professionals as well as the connection among OCB and GEN Y IT professionals.

Design/methodology/approach- This study has collected all the data from the conduction of primary quantitative data collection method which has assisted the researcher to gather the essential data from the responses from the GEN Y IT professionals. In addition, the inclusion of random sampling technique and measurement technique has assisted the researcher to conduct the research in a succinct way. However, 100 employees have been selected from Indian IT background, which has aided the researcher to gain factual data regarding the purpose of this research study.

Findings- Though analyzing the result the researcher has gained several beneficial factors that can reduce the intention of turnover of the GEN Y IT professionals. Furthermore, the result of this research study has supported the researcher to measure the organizational strategies that may reduce the employee turnover ratio of an organization.

Research limitations/implications- Due to the pandemic situation of covid-19 situation, face-to-face interviews are not taken and there is also a lack of secondary resources.
\end{abstract}

Keywords- Generation Y, Indian IT sector, Organizations, Employees, Maslow's hierarchy of needs, employment, retention

\section{INTRODUCTION}

Presently, in the competitive world almost every organization is utilizing the Gen Y employees to stay competitive in the competitive world. In addition, the inclusion of Gen y employees can assist an organization to enhance their productivity through producing a reliable and effective quality of service. However, the GEN Y employees are also looking for good work-life balance and flexible working hours, thus they can provide their maximum efficiency in their daily activities. On the other hand, the implantation of Gen Y employees can assist an organization to produce unique and sustainable quality of goods which assist an n organization to stay competitive in the international market place. Moreover, to retain the turnover ratio of the GEN Y employees of Indian IT firms this research paper has aimed to assess the importance of organizational citizenship behavior on the retention of GEN Y employees.

Organizational citizenship behavior is an organizational process that motivates the employees to work more efficiently to develop the organizational structure of the organization. As per the words of Pham et al.(2019), the implantation of organizational citizenship behavior can assist an organization to maintain the workplace ethics which can aid an organization to maintain the capability of 
its employee. Furthermore, the process of organizational citizenship behavior can also assist the management of an organization to easily define the job role and job description to each of the employees which indicate a positive nature of growth on the development of the organization. In this research study, a holistic and factual viewpoint will be provided on the way organizational citizenship behavior is influencing the turnover intention of Generation Y employees in the IT firms of India.

\subsection{Problem statement}

In India the competitiveness remains massive among the IT firms; however, due to employee turnover most of the Indian IT firms are facing numerous issues in their networking process. However, prioritizing the culture and behavior of the employees can aid an organization to motivate their employees to work harder to enhance the productivity rate of the organization. In accordance with the words of Jiang et al. (2017), giving priority to the culture of the employees can support the organization to gain the loyalty and reliability of their employees, which reflect a positive nature of growth in the performance and efficiency of the organization. However, in India due to the diversity of various cultures it is quite tough for the IT firms to support each and every culture of the employees. Therefore, the utilization of organizational citizenship behavior can assist IT firms to enhance the employee turnover ratio though imposing a positive environment where the employee can feel free to work according to the requirement of the organization.

As per the views of Kim et al. (2020), the inclusion of organizational citizenship behavior can assist an organization to describe the job description and job role to the employees, thus the employees can gain a sufficient viewpoint regarding the task they are assigned with. On the other hand, currently, most of the IT firms are facing a negative impact on their productivity rate due to lack of GEN Y employees. Due to lack of retention of GEN Y employees numerous IT firms have faced a negative impact on the operational efficiency as well as on the development process of the organization. As mentioned by Zaki et al. (2018), lack of appropriate work schedule of the employees in India has been identified as the reason behind the lack of retention of GEN Y employees. On the other hand, lack of job satisfaction of the Gen Y employees has been recognized as one of the major reasons behind the turnover of the employees in Indian IT firms. In addition, the Gen Y employees are inclined to work under authentic guidelines and policies. Moreover, in India due to lack of applicable workplace policies and guidelines the employees do not get sufficient benefits in their workplace, as a result that leads to lack of employee satisfaction. In 2021 April to June the attrition ratio of IT industries was $8.03 \%$, which reflects a gloomy impact on the productivity of IT firms.

Table 1: Employee turnover ratio of Indian IT firm of 2021

\begin{tabular}{|l|l|}
\hline Year (2021) & $\begin{array}{l}\text { Employees turnover rate of } \\
\text { Indian IT firms }\end{array}$ \\
\hline April & $8.03 \%$ \\
\hline May & $7.38 \%$ \\
\hline June & $7.45 \%$ \\
\hline
\end{tabular}

(Source: Zaki et al. 2018)

Table 1, defines the employee turnover ratio of the Indian IT firms, which shows that the IT firms of India are facing a massive impact on their productivity due to lack of Gen Y employees. Thereby, the usage of organizational citizenship behavior can assist an organization to enhance the retention rate of the Gen $\mathrm{Y}$ employees through creating a positive workplace environment in the organization.

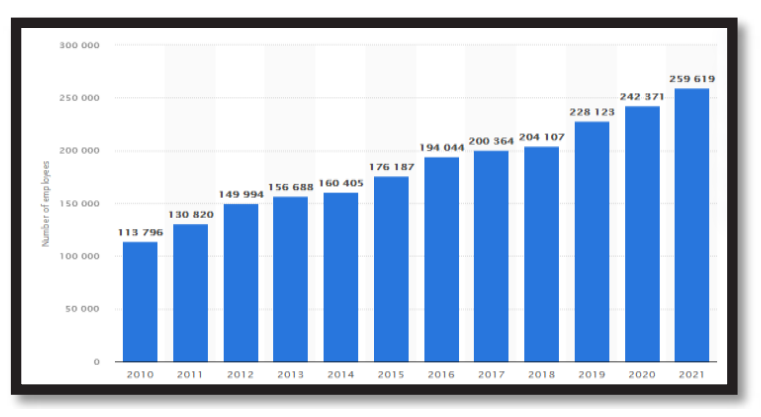

Figure 1: Number of employees in IT sector of India

(Source: Schneider and Harknett, 2019)

Through analyzing the figure it can be defined that the IT sector of India is gaining their number of employees in a succinct manner, however, that is still not sufficient enough to enhance the performance of the IT sector. As per the words of Schneider and Harknett (2019), in the world of technology the competitiveness among the IT firms has enhanced up to an extreme level. In order to remain sustainable and competitive the IT firms need a massive number 
of GEN Y employees in each of the IT firms of India. Chen and Tang (2019), stated that to maintain the product quality of IT firms, GEN Y employees will be one of the reliable choices for the IT sector. Hence, it can be easily defined that to enhance the performance and capability of the Indian IT sector one must enhance their GEN Y employee retention rate through the inclusion of organizational citizenship behavior.

\subsection{Thrust and Motivation}

The main purpose of this research is to critically evaluate the importance of organizational behavior culture to enhance the retention rate of the GEN Y employees in Indian IT firms. In accordance with the words of Blake et al. (2017), inclusion of proper policies and employee act can assist an organization to enhance the job satisfaction of the employees. As a result, that reflects a positive impact on the performance of the organization as well as on the retention rate of the organization. On the other hand, identification of the reason behind the employee turnover can also assist an organization to enhance the employee retention rate of an organization through mitigating the requirement of the employees. In addition, the inclusion of organizational citizenship behavior can also aid an organization to enhance their employee turnover rate. As the implantation of organizational citizenship behavior can support an organization to understand the culture of each employee that reflects a positive understanding among the employees and management of the organization (Gochhayat et al., 2017, Samanta, 2019). Moreover, this research study will support the researcher to provide a critical and factual overview regarding the way organizational citizenship behavior can assist the IT sector to enhance the retention rate of GEN Y employees.

\subsection{Aim and Objectives}

The aim of this research study is to critically identify the way organizational citizenship behavior can aid the retention rate of GEN Y employees in the Indian IT sector. In addition, all of the essential objectives have been arranged in a systematic way to identify and estimate the impact of organizational citizenship behavior to reduce the turnover ratio of the GEN Y employees in Indian IT firms.

The research objectives are given below:

- To critically analysis the concept and the efficiency level of GEN Y employees
- To recognize the difficulties GEN Y employees are facing in the infrastructure of the Indian IT sector.

- To recommend effective strategies regarding the implantation of organizational citizenship behavior to reduce the turnover rate of GEN Y employees.

- To critically assess the connection among organizational citizenship behavior and GEN Y employees.

- $\quad$ To critically analyze the way GEN Y employees get influenced to work harder for the development of IT firms through the inclusion of organizational citizenship behavior.

\subsection{Details on Generation Y}

Generation Y can be defined as the Millennial or internet generation, since generation $\mathrm{Y}$ has the potential to work appropriately regarding the goals of the organization. However, demographic characteristics such as age and behavior have a direct impact on the personality and the potential of an employee. In accordance with the words of Ladhari et al. (2019), the term GEN Y was first coined through a magazine called the Advertising age in 1993 mainly to indicate this generation as the last one to have been born within the twentieth century. However, employees of this generation have the capability to focus on their work life, which reflects a positive nature of growth in the development of an organization. On the other hand, GEN Y who is also called as the Millennial has the capability to follow Generation $\mathrm{X}$ and proceed with Generation $\mathrm{Z}$. furthermore, this research paper tried to make an attempt to connect GEN Y and organizational citizenship behavior to reduce the employee turnover rate in the Indian IT sector.

\section{RESEARCH BACKGROUND}

GEN Y employees are one of the efficient employees within an organization that has a massive impact towards the evolution process of a company. In addition, the GEN Y employees are also imposing a significant impact regarding increasing the turnover ratio of an organization. As per the words of Kaur et al. (2020), GEN Y employees are more inclined to contribute towards the enhanced productivity of the organization that may impose a significant impact towards the operational efficiency of the company. Moreover, according to several research studies, it has been determined due to lack of organizational citizenship behavior the retention 
rate of the GEN Y employees. Thereby, in order to enhance retention rate of the employees this research paper is aimed to influence the process of organizational citizenship behavior for increasing the turnover rate of the GEN Y employees.

As denoted by Haled et al. (2020), organizational citizenship behavior is a process within an industry that is determined to detect the factors that can encourage the employees thus the employees can utilize their maximum potential for the expansion of the company. On the other hand, the implication of this approach can also support an organization to reduce the negative factors regarding cultural diversity. Cultural diversity is one of the major factors which have deducted the employee turnover rate of the GEN Y employees. Apart from that, people born 1981 to 1996 are generally considered the GEN Y employees. However, in the context of IT firms, GEN Y employees have a massive influence towards the expansion of the organization.

For example: Massive IT firms such as Infosys, TCS are generating a fundamental amount of revenue through prioritizing the GEN Y employees within the workplace. In addition, it has been determined that GEN Y employees are more inclined to have a better work experience that can aid the organization to improve the operational efficiency of the organization. Therefore, in order to maintain the retention rate of the GEN Y employees and organization needs to practice effective activities for influencing the notion of organizational citizenship behavior. As a result it can aid the IT firms to increase the retention rate of the GEN Y employees. However, in this study, a logical overview will be presented regarding the way IT firms can utilize the notion of organizational cultural behavior for influencing the retention rate of the GEN Y employees.

\subsection{Theoretical development and Literature Review}

\section{Maslow's Hierarchy of Needs theory}

The notion of Maslow's hierarchy of needs theory is to motivate the employees thus they can provide their maximum potential for increasing the turnover rate of an organization. As per the words of Ștefan et al. (2020), this theory is the motivational theory that can comprise a five tier model of human needs. On the other hand, it is depicted as the hierarchical levels within a pyramid that can aid an organization to motivate its employees. In addition, through the incorporation of this theory an organization can easily detect the needs of the employees, which is really essential for increasing the transparency of the company. Apart from that, the implication of this theory can also aid an organization to impose a positive nature of environment within the workplace that can aid in the evolution phase of the company. Hence, through analyzing the positive factors of this theory it has been determined that the IT firms can easily utilize this theory for influencing the retention rate of the GEN Y employees.

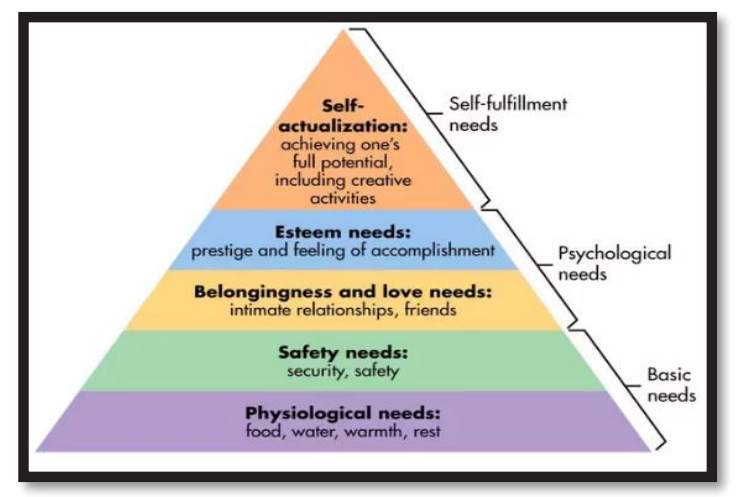

Figure 2: Maslow's Hierarchy of Needs theory

(Source: Ștefan et al. 2020)

Edgar Schein cultural framework theory

Edgar Schein cultural framework theory is also an essential theory that can be taken under consideration for increasing the motivations of the employees. According to several prior published journals and study, it has been determined that this theory stands for eliminating the negative effects of cultural diversity within an organization that can impose a magnificent impact on the expansion of an organization. As mentioned above, due to lack of organizational cultural behavior the Indian IT firms are facing some disruption in order to maintain the turnover rate of the GEN Y peoples. In this regard, Indian IT firms can correspond with the notion of Edgar Schein cultural framework theory.

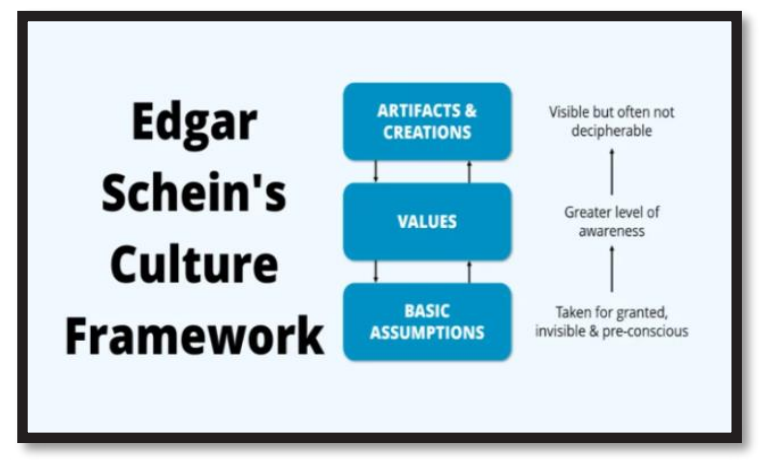

Figure 3: Edgar Schein cultural framework

(Source: Shanafelt et al. 2019) 


\subsection{Theoretical Development}

GEN Y employees are the most fundamental resources of the IT firms, as they are contributing a massive percentage towards the evolution of the IT Firms. For example: TCS is the leading IT firm in India that is motivating its GEN Y employees to enhance the operational efficiency of the organization. However, in order to enhance the retention rate of the GEN $\mathrm{Y}$ employees and organization must improve its organizational cultural behavior. Organizational cultural behavior can reward the employees as per their contribution towards the organization. On the other hand, it also aids an organization to respect the values and beliefs of the employees. Hence, it is justifiable that the implication of organizational cultural behavior can aid the Indian IT firms to increase the retention thinking of the GEN Y employees.

Organizational citizenship behavior is demonstrated by various decisions related to career progression. Its first and second hypothesis is formulated as

H1: The OCB helps in the growth of the organizational culture for reducing employee turnover.

H2: The OCB helps in the up-gradation of the organizational motivational culture for reducing employee turnover.

The research analyzed that there is a widespread relationship between citizenship behavior and job experience. This hypothesis gives concern for not reducing the employee turnover in the IT firms in India.

Therefore the third and fourth hypothesis is formulated as

H3: The OCB helps to develop the work culture and work pressure for reducing employee turnover.

H4: The OCB keeps increasing the learning process and training for reducing the employee turnover in IT firms.

The OCB describes that there should be the development of the work culture and workload in the IT firms. The training should be regular for reducing the turnover in the IT firms in India.

\section{RESEARCH METHODOLOGY}

Research methodology is one of the vast chapters of a research study which is essential to conduct a credible and reliable research study. Through analyzing the subject or nature of this researcher's study the researcher has decided to prepare a survey among 100 GEN Y employees from the IT sector.
The questionnaire was distributed among the GEN Y IT employees through the usage of internet email service. Due to the pandemic of COVID 19 it was not possible for the researcher to conduct face to face interviews among the employees. Thereby, the researcher has utilized the questionnaire survey process to gather sufficient data regarding the research topic. On the other hand, the researcher has prioritized the job experiences of the GEN Y employees, since to gain the factual data regarding the research study job experience will be a reliable factor for the researcher. GEN Y employees who have experience for more than 2 years, the researcher has selected those employees for this survey conduction. Furthermore, the responses of the employees have been analyzed through the usage of 5-point liker scale to collect the responses of the GEN Y employees.

\subsection{Sampling Technique}

Simple random sampling methods have been selected for this study to collect data regarding the topic. According to Affleck (2018), random sampling is beneficial for any study as it takes less time and can be finished effectively. Henceforth, this sampling method was selected for this study that also helped to interpret the results in a suitable manner.

\subsection{Sample Size}

In order to collect data for this research the researcher has conducted a survey on 100 participants working in the IT sectors of India. However, a questionnaire with demographic and liker scale format is developed in this study for meeting the objectives of this study. In this regard, 2 demographic and 8 liker scale questions related to the concerned topic of this study are made by the researcher for interpreting the results in a proper manner.

\subsection{Data Collection Method}

Data collection method is one of the most essential parts of a research study, since the proper selection of appropriate data collection methods can assist the researcher to conduct the findings of a research study in a precise way. As per the words of Rahmatizadeh et al. (2018), in the conduction process of a research study, there two types of data collection method can be found. In this research study the researcher has selected the primary data collection method to gather factual data regarding the research study. As the dataset of primary data 
collection method can be used to gain all the essential data regarding the subject of a research study. In this research study, primary quantitative data collection method has been used to provide more reliable and factual data for the conducting the research study in a succinct way.

\subsection{Data Analysis Technique}

The data analysis technique can be defined as the understanding of the data which has been collected from the primary data collection method. In accordance with the words of Al-Qurabat et al. (2018), the data collection method is part of a research study that assesses the collected data of a research study, thus the researcher can provide meaningful insights to prepare the research study. Furthermore, it is essential for a researcher to focus on the data analysis technique as it assists the researcher to conduct the further stage of the research study. Moreover, in the process of collecting relevant data there may be several difficulties that can occur. However, the inclusion of data analysis techniques can aid a researcher to solve these kinds of difficulties regarding the research study. Therefore, in order to identify the potential difficulties of a research study and to reduce the negative impact of the issues, the data analysis technique will be a valuable aspect for this research study.

\subsection{Measures}

In order to estimate the quality of this research study the researcher has utilized the concept of measure of data collection. As per the words of Hu et al. (2020), the inclusion of proper measure technique in a research study can assist a researcher to provide a sustainable and logical viewpoint regarding the findings of the research study. In addition, through analyzing the nature of this research study the researcher has collected all the data from the feedback of the responses. However, the measure technique has supported the researcher to check the validity and reliability of the collected data regarding the research study.

\subsection{Procedure}

A similar questionnaire set has been prepared to distribute among each sample among the selected GEN Y IT employees. The selected participants pop this survey is working in various IT companies across India, and they have shared their personal feedback without any manipulation regarding the research study. However, the process of data collection procedure is one of the most essential parts to conduct a credible and reliable research study. The feedback of the respondent has been analyzed through the usage of 5-point liker scale.

\section{RESULT AND ANALYSIS}

In order to precisely analyze the collected data to precede this part of the research study, the researcher has utilized SPSS software. As per the words of Purwanto et al.(2021), the inclusion of SPSS software can assist a researcher to gain sufficient data regarding the conduction of a research study. As the usage of SPSS software can assist research to conduct the correlation, regression and frequency test. As a result, that reflects a positive nature of outcome on the preparation of the research study. In this research study, the researcher has conducted descriptive statistics, $\mathrm{T}$ test, reliability test and frequency test to conduct the research in an appropriate manner.

Table 2: Descriptive statistics

\begin{tabular}{|c|c|c|c|c|c|c|c|c|}
\hline ics & & & & & & & & \\
\hline & $\begin{array}{l}\text { Lack of } \\
\text { job } \\
\text { satisfactio } \\
\mathrm{n} \text { is one of } \\
\text { the reason } \\
\text { behind } \\
\text { employee } \\
\text { turnover } \\
\text { in Indian } \\
\text { IT sector }\end{array}$ & $\begin{array}{l}\text { Cooperatio } \\
\mathrm{n} \text { among } \\
\text { the } \\
\text { manageme } \\
\text { nt and GEN } \\
\mathrm{Y} \\
\text { employees } \\
\text { can reflect } \\
\text { surprising } \\
\text { growth on } \\
\text { the } \\
\text { developme } \\
\text { nt of an } \\
\text { organizatio }\end{array}$ & $\begin{array}{l}\text { Toxic } \\
\text { workplace } \\
\text { environme } \\
\text { nt can } \\
\text { provide } \\
\text { gloomy } \\
\text { outcome } \\
\text { on the } \\
\text { performanc } \\
\text { e of IT } \\
\text { sector }\end{array}$ & $\begin{array}{l}\text { Organizati } \\
\text { onal } \\
\text { citizenship } \\
\text { behavior } \\
\text { can } \\
\text { support an } \\
\text { organizati } \\
\text { on to } \\
\text { motivate } \\
\text { its } \\
\text { employees }\end{array}$ & $\begin{array}{l}\text { Emplace } \\
\text { ment act } \\
\text { and } \\
\text { policies } \\
\text { can } \\
\text { enhance } \\
\text { the } \\
\text { employe } \\
\text { e } \\
\text { retentio } \\
n \text { rate }\end{array}$ & $\begin{array}{l}\text { Inappropri } \\
\text { ate } \\
\text { infrastruct } \\
\text { ure can } \\
\text { enhance } \\
\text { the } \\
\text { employee } \\
\text { turnover } \\
\text { ratio of } \\
\text { Indian IT } \\
\text { sector }\end{array}$ & $\begin{array}{l}\text { Organizatio } \\
\text { nal } \\
\text { citizenship } \\
\text { behavior } \\
\text { support the } \\
\text { characteristi } \\
\text { cs of GEN } \\
\text { Y } \\
\text { employees }\end{array}$ & $\begin{array}{l}\text { GEN Y } \\
\text { employees } \\
\text { are like to } \\
\text { work in a } \\
\text { positive } \\
\text { atmospher } \\
\text { e }\end{array}$ \\
\hline
\end{tabular}




\begin{tabular}{|l|l|l|l|l|l|l|l|l|}
\hline & & $\mathrm{n}$ & & & & & & \\
\hline $\mathbf{N}$ & $\mathbf{N}$ & 101 & 101 & 101 & 101 & 101 & 101 & 101 \\
\cline { 2 - 10 } & 101 & 0 & 0 & 0 & 0 & 0 & 0 & 0 \\
\hline Mean & 3.49 & 3.52 & 3.77 & 3.89 & 4.46 & 3.92 & 3.82 & 3.38 \\
\hline $\begin{array}{l}\text { Std. Error } \\
\text { of Mean }\end{array}$ & .140 & .126 & .141 & .142 & .105 & .143 & .108 & .144 \\
\hline $\begin{array}{l}\text { Std. } \\
\text { Deviation }\end{array}$ & 1.411 & 1.270 & 1.413 & 1.428 & 1.054 & 1.433 & 1.090 & 1.448 \\
\hline
\end{tabular}

(Source: SPSS)

As defined in table number 2, it can be easily demonstrated that the mean value of "Emplacement act and policies can enhance the employee retention rate" is 4.46 . Therefore, it can be easily defined that the "Emplacement act and policies can enhance the employee retention rate" has a direct impact on the enhancement of employee retention rate. In addition, the Std. Error of Mean value of "GEN Y employees

\section{Frequency Test}

Table 3: t-test (Hypothesis Testing)

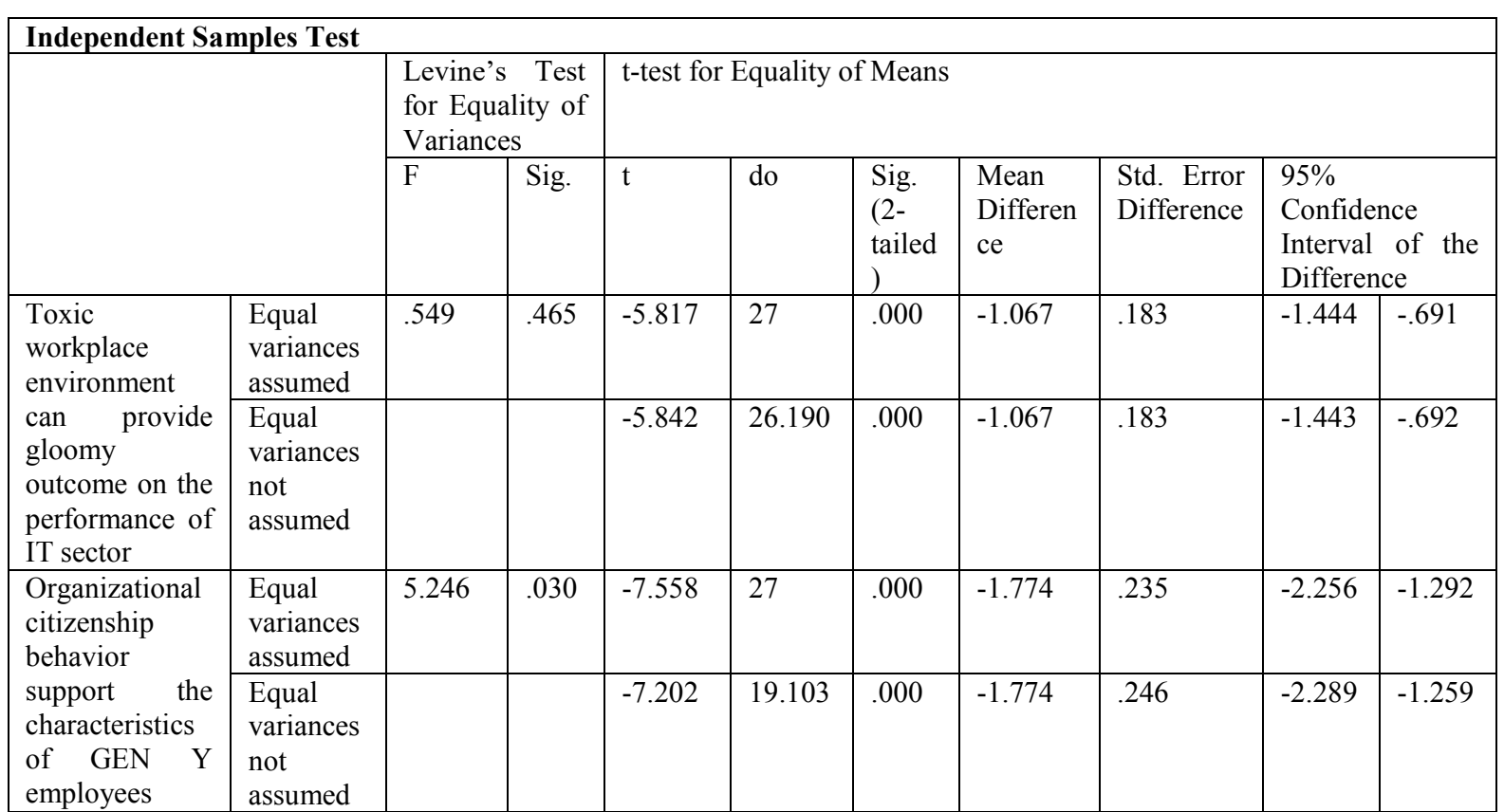

are likely to work in a positive atmosphere" is .144, which shows this statement has a direct connection with the purpose of this research study. On the other hand, the Std. Deviation value of "Organizational citizenship behavior can support an organization to motivate its employees" is 1.428 , which shows this statement can also impose a positive nature of impact on the employee retention rate.
(Source: SPSS)

Table number 3 has provided a holistic viewpoint regarding the result of the Hypothesis t-testing.

As per the T-test the researcher has developed hypothesis which are stated below:

H1: The organizational citizenship behavior can assist an organization to enhance retention rate of generation Y employees in the Indian IT sector.

The calculated value of Mean Difference is (1.774) that was less than the effective level (0.05). Hence, it can be easily defined that to enhance the retention rate of the employees an organization must need to utilize the organizational citizenship behavior in the Indian IT sectors.

H2: Toxic workplace can impose a negative outcome on the retention rate of the GEN Y IT professionals in the Indian IT sectors.

The calculated value of Mean Differences is (1.067), which is less than the effective level (0.05). Thereby it can be easily stated that a toxic workplace environment can impose a negative impact on the employee retention rate of Indian IT sectors. 
Table 4: Reliability statistics

\begin{tabular}{|l|lr|}
\hline \multicolumn{3}{|l|}{ Reliability Statistics } \\
\hline $\begin{array}{l}\text { Cronbach's } \\
\text { Alpha }\end{array}$ & $\begin{array}{l}\text { Cronbach's Alpha } \\
\text { Based on } \\
\text { Standardized Items }\end{array}$ & N of Items \\
\hline .924 & .938 & 3 \\
\hline
\end{tabular}

(Source: SPSS)

As highlighted in table number 4, the "Cronbach's Alpha" value is .924 and the value of "Cronbach's Alpha Based on Standardized Items" is 938. As a result, that significantly shows that the data which has been collected in this research study has assisted the researcher to conduct a reliable and credible research study.

\section{DISCUSSION AND FINDING}

As highlighted in the result part, the inclusion of several strategies can aid an IT sector to enhance their employee retention rate. As per the words of Farid et al. (2019), the inclusion of organizational citizenship behavior can assist an IT sector to establish an efficient engagement with their employees. As a result, that reflects a positive impact on the performance of the organization through enhancing the employment rate of the organization. In addition, the inclusion of organizational citizenship behavior can also assist the GEN Y IT professionals to connect with the value of an organization which supports the employees to work harder to assist the organization to achieve their goals.

On the other hand, to enhance the retention rate of the GEN Y IT professionals an organization must need to enhance their workplace environment. As shown in the previous part, the toxic environment of an organization can highly impact the employee retention rate of an organization. Through practicing employment acts and effective policies an organization can easily enhance the positivity of their workplace environment which imposes a positive impact on the performance of the organization. Furthermore, to retain the employees of GEN Y, understanding the culture of the GEN Y employees is also one of the essential parts of an organization to reduce the employee's turnover of Indian IT firms. Moreover, the usage of organizational citizenship behavior can aid the IT firms to understand the desires and amenities of each of GEN Y employees of IT firms, as a result, that support the IT firm to establish a strong and positive connection among the employees of GEN Y IT professionals. Furthermore, the research study has performed several tests to highlight the importance of organizational citizenship behavior to reduce the rate of employee turnover rate.

\section{IMPLICATIONS OF STUDY}

Future researchers can incorporate the other variables such as the consequences of the OCB like the employee commitment to be increased, performances, job satisfaction, and organizational effectiveness. The other negative consequences can be studied for enrichment in the field of research. Employer retention has an attention for the top-level managers in any of the IT organizations because the organizational and personal costs of leaving the job are too high. The dimensions like sportsmanship and altruism improve the organizational capacity for retaining and attracting the best employees.

\section{LIMITATION AND SCOPE FOR FURTHER RESEARCH}

The OCB is the term that is used to describe the constructive and positive actions of the employees and also the behaviors that are not part of the formal job description. OCB is not required to form the employees for doing their jobs and it is also not part of the contractual tasks (Kaur et al. 2020). There are several opinions regarding OCB because the selfrating and supervisor rating have their advantages and then disadvantages. It is fully dependent on the nature of constructing the environment of the IT firms.

\section{CONCLUSIONS}

As per the above study it has been determined that through increasing the positivity of the organizational cultural behavior an organization can easily decrease the turnover rate of GEN Y employees. In this regard the researcher has proposed a holistic viewpoint regarding the way organizational cultural behavior can motivate the GEN Y employees to utilize their maximum efficiency towards the evolution of the company. In the Indian IT firms it has been detected that due to poor organizational cultural behavior the IT firms are facing aviation in turnover rate of the employees. On the other hand, the researcher has obtained data from the GEN Y employees regarding the way OCB can influence the performances of the employees. Apart from that, they obtained information has been interpreted within the SPSS software. However, the result of the analysis has shown that the inclusion of OCB has a positive influence towards increasing the retention rate of GEN Y employees in IT firms. 


\section{REFERENCES}

[1] Abdulmuhsin, A.A., Zaker, R.A. and Asad, M.M., How exploitative leadership influences on knowledge management processes: the moderating role of organisational citizenship behavior. International Journal of Organizational Analysis, 2021.

[2] Affleck, D.L., Estimating desired sample size for simple random sampling of a skewed population. The American Statistician, 72(2), pp.184-190, 2018.

[3] Al-Qurabat, A.K.M. and Idrees, A.K., Energyefficient adaptive distributed data collection method for periodic sensor networks. International Journal of Internet Technology and Secured Transactions, 8(3), pp.297-335, 2018.

[4] Blake, L., Francis, V., Johnson, J., Khan, M. and McCray, T., Developing robust data management strategies for unprecedented challenges to healthcare information. Journal of Leadership, Accountability, and Ethics, 14(1), pp.22-31, 2017.

[5] Chen, C. and Tang, L., BIM-based integrated management workflow design for schedule and cost planning of building fabric maintenance. Automation in construction, 107, p.102944, 2019.

[6] Farid, T., Iqbal, S., Ma, J., Castro-González, S., Khattak, A. and Khan, M.K., Employees' perceptions of CSR, work engagement, and organizational citizenship behavior: The mediating effects of organizational justice. International journal of environmental research and public health, 16(10), p.1731, 2019.

[7] J Gochhayat, V.N. Giri, D. Suar, Multilevel leadership and organizational effectiveness in Indian technical education: the mediating role of communication, power and culture, International Journal of Leadership in Education 20(4) (2017) 491-505, DOI: $10.1080 / 13603124.2015 .1135254$

[8] Halid, H., Kee, D.M.H. and Rahim, N.F.A., Perceived Human Resource Management Practices and Intention to Stay in Private Higher Education Institutions in Malaysia: The Role of Organizational Citizenship Behavior. Global Business Review, p.0972150920950906, 2020.
[9] Hu, T. and Chen, O., On a family of coherent measures of variability. Insurance: Mathematics and Economics, 95, pp.173-182, 2020.

[10] Jena, L.K. and Pradhan, S., Workplace spirituality and employee commitment: The role of emotional intelligence and organizational citizenship behavior in Indian organizations. Journal of Enterprise Information Management, 2018.

[11] Jiang, W., Zhao, X. and Ni, J., The impact of transformational leadership on employee sustainable performance: The mediating role of organizational citizenship behavior. Sustainability, 9(9), p.1567, 2017.

[12] Kaur, P., Malhotra, K. and Sharma, S.K., Employer branding and organisational citizenship behavior: The mediating role of job satisfaction. Asia-Pacific Journal of Management Research and Innovation, 16(2), pp.122-131, 2020.

[13] Kim, W.G., McGinley, S., Choi, H.M. and Agmapisarn, C., Hotels' environmental leadership and employees' organizational citizenship behavior. International Journal of Hospitality Management, 87, p.102375, 2020.

[14] Ladhari, R., Gonthier, J. and Lajante, M., Generation $\mathrm{Y}$ and online fashion shopping: Orientations and profiles. Journal of retailing and Consumer Services, 48, pp.113-121, 2019.

[15] Pham, N.T., Tučková, Z. and Jabbour, C.J.C., Greening the hospitality industry: How do green human resource management practices influence organizational citizenship behavior in hotels? A mixed-methods study. Tourism Management, 72, pp.386-399, 2019.

[16] Purwanto, A., Asbari, M. and Santoso, T.I., Analisis Data Penelitian Sosial dan Manajemen: Perbandingan Hasil antara Amos, SmartPLS, WarpPLS, dan SPSS Untuk Jumlah Sampel Medium. International Journal of Social and Management Studies, 2(4), pp.43-53, 2021.

[17] Rahmatizadeh, S., Rajabifard, A., Kalantari, M. and Ho, S., A framework for selecting a fit-forpurpose data collection method in land administration. Land use policy, 70, pp.162171, 2018.

[18] S.R. Samanta, Soft Competency in Corporate Management, Parikalpana: KIIT Journal of Management 15 (1/2) (2019) 293-294. 
[19] Schneider, D. and Harknett, K., Consequences of routine work-schedule instability for worker health and well-being. American Sociological Review, 84(1), pp.82-114, 2019.

[20] Shanafelt, T.D., Schein, E., Minor, L.B., Trockel, M., Schein, P. and Kirch, D., Healing the professional culture of medicine.In Mayo Clinic Proceedings (Vol. 94, No. 8, pp. 15561566).Elsevier, 2019, August.

[21] Ștefan, S.C., Popa, Ș.C. and Albu, C.F., Implications of Maslow's hierarchy of needs theory on healthcare employees' performance. Transylvanian Review of Administrative Sciences, 16(59), pp.124-143, 2020.

[22] Zaki, A., Elalim, A.M.A. and El Samadony, A., Factors Affecting Schedule Delay and Cost Overrun in Egyptian Construction Projects. In Proceedings of the 2nd International Conference Sustainable Construction and Project Management-Sustainable Infrastructure and Transportation for Future cities, Aswan, Egypt (pp. 16-18), 2018, December.

\section{Annexure:}

\begin{tabular}{|c|c|c|c|c|c|c|}
\hline \multicolumn{7}{|l|}{ One-Sample Test } \\
\hline & \multicolumn{6}{|c|}{ Test Value $=0$} \\
\hline & \multirow[b]{2}{*}{$\mathrm{t}$} & \multirow[b]{2}{*}{ df } & \multirow{2}{*}{$\begin{array}{l}\text { Sig. (2- } \\
\text { tailed) }\end{array}$} & \multirow{2}{*}{$\begin{array}{l}\text { Mean } \\
\text { Difference }\end{array}$} & \multicolumn{2}{|c|}{$\begin{array}{l}95 \% \text { Confidence } \\
\text { Interval of the } \\
\text { Difference }\end{array}$} \\
\hline & & & & & Lower & Upper \\
\hline $\begin{array}{l}\text { Lack of job satisfaction is one of the } \\
\text { reason behind employee turnover in } \\
\text { Indian IT sector }\end{array}$ & 24.815 & 100 & .000 & 3.485 & 3.21 & 3.76 \\
\hline $\begin{array}{l}\text { Organizational citizenship behavior } \\
\text { can support an organization to } \\
\text { motivate its employees }\end{array}$ & 27.392 & 100 & .000 & 3.891 & 3.61 & 4.17 \\
\hline $\begin{array}{l}\text { Inappropriate infrastructure can } \\
\text { enhance the employee turnover ratio of } \\
\text { Indian IT sector }\end{array}$ & 27.496 & 100 & .000 & 3.921 & 3.64 & 4.20 \\
\hline
\end{tabular}
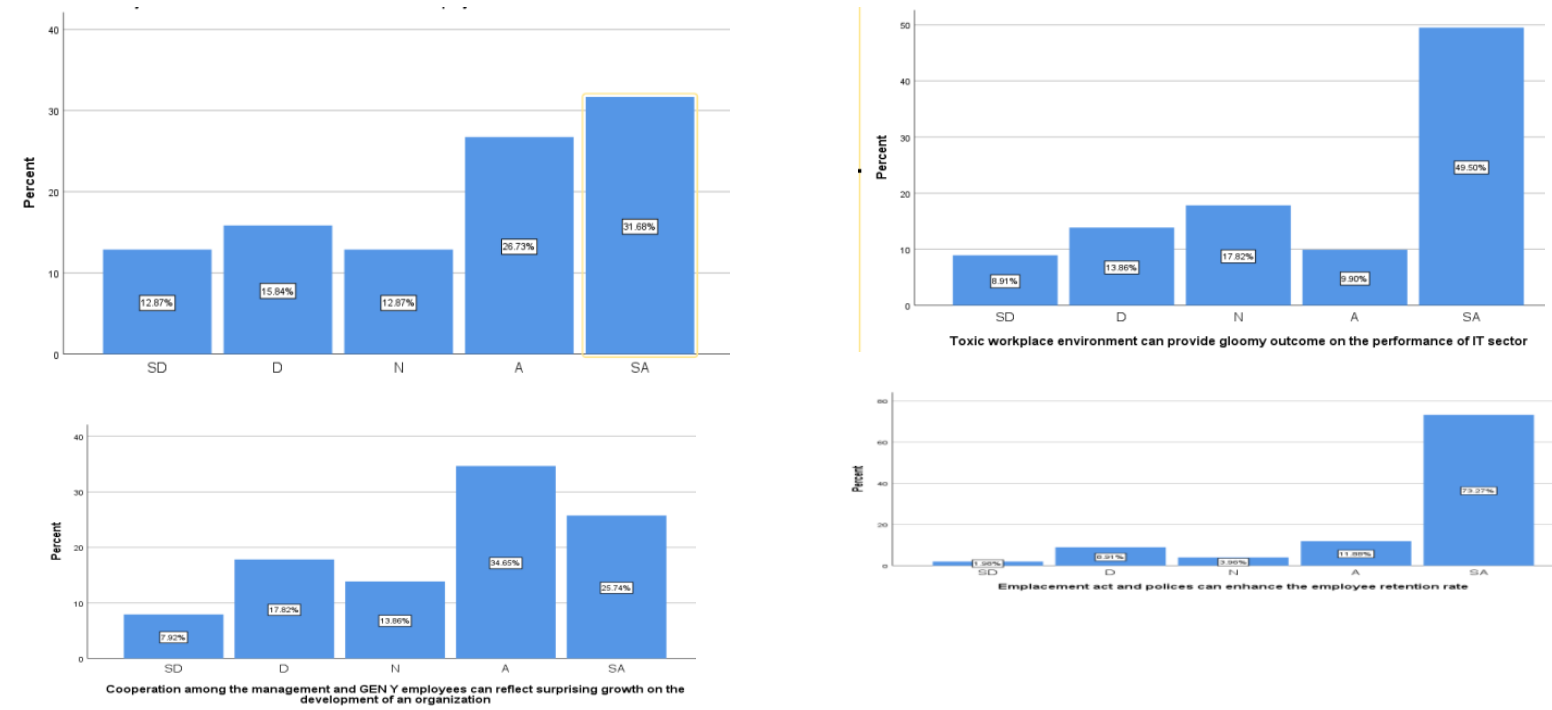

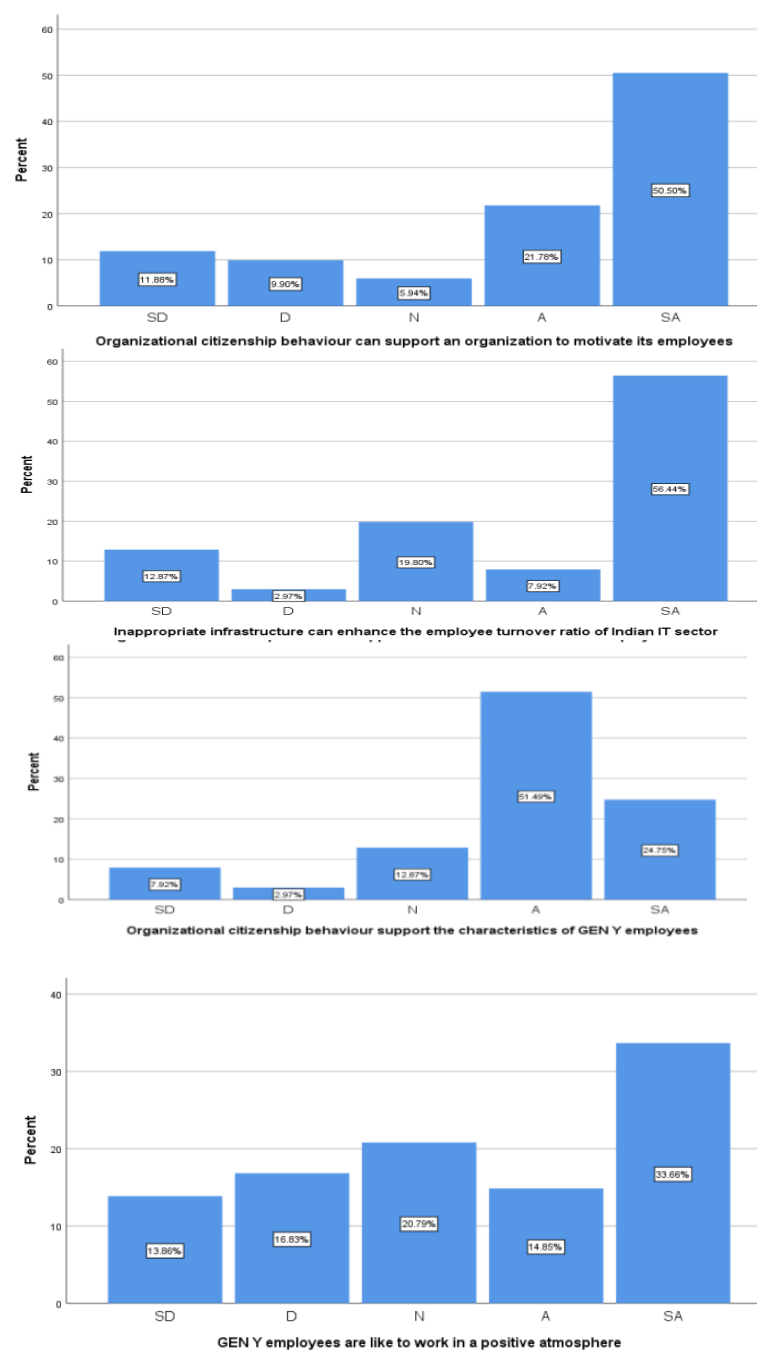